\title{
A STUDY OF BACTERIAL CONTAMINATION OF RATTLESNAKE VENOM
}

\section{E. Garcia-Lima and C.J. Laure}

\author{
The authors studied the bacterial contamination of rattlesnake venom isolated \\ from snakes in captivity and wild snakes caught recently. The captive snakes showed a \\ relatively high incidence of bacterial contamination of their venom.
}

Key words: Rattlesnake venom. Bacterial contamination.

Several investigators have studied cold-blooded animals in terms of contamination by different types of organisms. Hinshaw and $\mathrm{McNeil}^{4}$ isolated Salmonella rubislaw from 3 out of 12 Sceloporus occidentalis specimens. Zwart ${ }^{24}$ reported the isolation of Salmonellae from $37.5 \%$ of lizards. LeNoc and $\mathrm{Brygoo}^{9}$ isolated 58 different types of salmonellae from 48 out of 127 chameleons examined.

In studies on snakes captured in Pará and in lower Amazonia (Brazil), Lins ${ }^{1011}$ showed that $11.31 \%$ of the animals examined were infected with salmonellae. Kourany et al. ${ }^{8}$ detected salmonellae in 27.3\% of lizards and $6.5 \%$ of toads examined. Moreno et al ${ }^{14}$, in a study of 613 cold-biooded animals raised in captivity, most of which were snakes, detected in 271 animals several bacterial species, such as Citrobacter, Proteus vulgaris, Proteus morganii and Proteus rettgeri as well as several types of salmonellae. This led the authors to emphasize the high incidence of contamination with salmonellae among snakes.

Despite good physiological conditions of the snakes several investigators have found high indices of contamination. Thus, Furlanetto et al ${ }^{3}$ detected high levels of contamination with enterobacteriaceae and other bacteria in an epizooty caused by a diphtheroid bacterium among snakes raised in an animal house. This bacillus caused a disease among these snakes that had not been reported before. The disease affected $70.0 \%$ of snakes of the genera Bothrops and Crotalus whose venom was going to be used for the preparation of antibothrops and anticrotalus sera. The snakes were vaccinated with a Wright-type vaccine prepared from the diphtheroid bacillus detected, which was highly effective in lowering the level of infection from $70 \%$ to $0.4 \%$.

Several investigators have attempted to establish a bacterial standard for the mouth flora of snakes

Department of Parasitology, Microbiology and Immunology and Department of Biochemistry, Faculty of Medicine of Ribeirão Preto, University of São Paulo. 14049 Ribeirão Preto, SP, Brazil.

Recebido para publicação em 25/2/1986. and have reported the presence of several bacterial species ${ }^{1} 5618192123$. Soerensen et al ${ }^{20}$ described "single visceral drop" disease affecting snakes in captivity. Furlanetto et al ${ }^{3}$ reported a type of infection of the venom glands of Bothrops linneaeus. 1758, and Crotalus wagler, 1824, raised in the animal house.

Marcus ${ }^{13}$ detected "mouth rot" in the upper and lower gums of snakes, and Wallach 22 had also found inflammation of the gums and dental arches of snakes. This type of inflammation caused large amounts of yellowish exudate which later induced secondary osteomyelitis. Klingelhoeffer ${ }^{7}$ had also reported two acute forms of "mouth rot" that led to the death of affected snakes. Several other agents such as Aeromonas ${ }^{17}$ and P. liquefaciens, Pasteurella and Proteus sp. ${ }^{19}$ were reported to be responsible for this type of disease.

In view of the wide interest shown by many researchers in studying cold-blooded animals for infections caused by bacteria and by other microorganisms, we decided to determine the bacterial contamination present in the venom of rattlesnakes, using both wild animals and animals raised in captivity.

\section{MATERIALS AND METHODS}

The materials used were rattlesnake (Crotalus durissus terrificus) venom and blood-agar bacterial growth medium. The venom was obtained from recently captured rattlesnakes ( 1 day) and from snakes held in captivity. Venom was obtained from young and adult male and female snakes restrained in the usual manner, by applying pressure to the venom glands. To avoid bacterial contamination of the sterilised venom flask, they were covered with plastic film during collection. Only the snake's fangs were allowed to perforate the plastic film, with the venom being deposited into the flask free from environmental contamination.

Immediately after collection, the venom samples were placed on a blood-agar plate with the aid of a platinum wire. The plates were incubated for 24 hours at $37^{\circ} \mathrm{C}$ and examined. The colonies detected on the 
Garcia Lima E, Laure CJ. A study os bacterial contamination or rattlesnake venom. Revista da Sociedade Brasileira de Medicina Tropical 20: 19-21, Jan-Mar, 1987.

plates were examined and the microorganisms identified.

\section{RESULTS}

A total of 480 rattlesnakes were examined; 450 of them belong to the animal house of a private laboratory in the State of São Paulo, and the remaining 30 to the animal house of the Faculty of Medicine of Ribeirão Preto, University of Sāo Paulo. The first group is maintained under controlled temperature and humidity conditions, and the second in an open animal pit. The snakes from the private laboratory were divided into two groups: 360 snakes held in captivity and 90 being held in quarantine after being captured ( 1 day earlier). The snakes belonging to the animal house of the Faculty of Medicine have been captive for a long time. The animals belonging to the private laboratory originated from Bauru, State of São Paulo.

Venom contamination was detected in 42 snakes, as shown in Table 1 . The incidence of the microorganisms involved is shown in Table 2.

Table 1-Distribution and origin of contaminated snakes.

\begin{tabular}{|c|c|c|c|c|c|}
\hline \multirow[t]{2}{*}{ Origin } & \multicolumn{2}{|l|}{ Captivity } & \multicolumn{2}{|l|}{ Quarantine } & \multirow[t]{2}{*}{ Total } \\
\hline & $\begin{array}{l}\text { Infected snakes/Total } \\
\text { number in the group }\end{array}$ & $1 \%$ & $\begin{array}{l}\text { Infected snakes/Total } \\
\text { number in the group }\end{array}$ & $\%$ & \\
\hline $\begin{array}{l}\text { Bauru } \\
\text { Faculty of Medicine o } \\
\text { Ribeirão Preto }\end{array}$ & $\begin{array}{c}35 / 360 \\
6 / 30\end{array}$ & $\begin{array}{r}9.7 \\
20.0\end{array}$ & $\begin{array}{c}1 / 90 \\
-\end{array}$ & 1.1 & $\begin{array}{r}36 \\
6\end{array}$ \\
\hline Total & $41 / 390$ & 10.5 & $1 / 90$ & 1.1 & $42 / 480$ \\
\hline
\end{tabular}

Table 2-Incidence of microorganisms among the snakes studied.

\begin{tabular}{lccc}
\hline Microorganism & Captivity & Quarantine & Total \\
\hline Bacillus subtilis & 7 & - & 7 \\
$\begin{array}{l}\text { Escherichia coli } \\
\begin{array}{l}\text { Monilia sp } \\
\text { Paracolobactrum }\end{array}\end{array}$ & 2 & - & 2 \\
$\quad$ aeroginoide & 1 & - & 3 \\
$\begin{array}{l}\text { Proteus vulgaris } \\
\text { Pseudomonas } \\
\quad \text { aeruginosa }\end{array}$ & 7 & - & 1 \\
$\begin{array}{l}\text { Shigella sp } \\
\text { Staphylococcus } \\
\quad \text { epidermides }\end{array}$ & 2 & - & 8 \\
$\begin{array}{l}\text { Streptococcus } \\
\text { haemolyticus }\end{array}$ & 22 & - & 2 \\
$\begin{array}{l}\text { Streptococcus beta } \\
\text { haemolyticus }\end{array}$ & 2 & - & 22 \\
Total & 52 & - & 4 \\
\hline
\end{tabular}

\section{DISCUSSION}

Several investigators have studied the contamination of cold-blooded animals, specially snakes, with particular emphasis on mouth contamination. Infections caused by salmonellae were detected by Hinshow and McNeil, ${ }^{4}$ Zwart, ${ }^{24}$ Le-Noc and Brygoo9, Lins ${ }^{1011}$ Kourany et al ${ }^{8}$ and Moreno et al ${ }^{14}$. Moreno et al $^{14}$ also detected other bacterial genera such as Citrobacter and Proteus. The high incidence of contamination with salmonella among snakes may be due to their crawling and to their feeding habits. However, the high incidence of contamination of low-body temperature animals with enterobacteriaceae is more difficult to explain, since these bacteria require higher temperatures to develop.

Conflicting results have been reported by the investigators who have studied the mouth flora of snakes 15618192123 . All the mouth infections of snakes lead to the death of the arimal.

In the present study, whose objetive was simply to study the contamination of venom, $8.75 \%$ of the captive snakes studied showed contamination as opposed to $1.11 \%$ of so-called wild snakes captured less than one day earlier. The wild snake was contaminated with a single bacterial genus, whereas several snakes held in captivity were contaminated with more than one genus of bacteria. These results suggest that contamination is due to handling which involves human contact and the consumption of contamined food and water 25121516 . The recently captured wild snake which was found to be contaminated may have been infected through handling, although it had been captive for only 24 hours. In view of the above considerations it is recommended that individuals bitten by snakes, in addition to being submitted to serum therapy, be also observed clinically for possible signs of bacteremia.

\section{RESUMO}

Os autores estudaram a contaminação bacteriana do veneno de cascavéis mantidas em cativeiro e das recentemente capturadas. Verificaram que os venenos dos animais cativos apresentaram alta incidência de contaminação $e$ os tidos como recentemente capturados estavam com baixa contaminação aparente.

Palavras chaves: Veneno de cascavel. Contaminação bacteriana.

\section{REFERENCES}

1. Aronson JD. Spontaneous tuberculosis in snakes. Archives of Pathology 8:159, 1929.

2. Dobbs JS. Reptilian disease recognition and treatment. Ralph Curtis Books, Hollywood, 1973.

3. Furlanetto RS, Belluomini HE, Lizuka H, Rosa RR. Epizootia provocada por bacilo difteróide em serpentes 
Garcia-Lima E, Laure CJ. A study os bacterial contamination or rattlesnake venom. Revista da Sociedade Brasileira de Medicina Tropical 20: 19-21, Jan-Mar, 1987.

mantidas em biotério. Revista de Microbiologia 10:139. $143,1979$.

4. Hinshaw WR, McNeil E. Lizards carriers of salmonella and paracolon bacteria. Journal of Bacteriology 53:715$718,1947$.

5. Jaksztien KP, Petzold HG. Durch Salmonella Infektion bedingte Schweirigkeiten bei der Anfzucht Schlangen und ihre Behandlung. VI. Ager Terrk 6:79-80, 1969.

6. Kauffeld CF. Newer treatment of mouth rot in snakes. Herpetologica 9:132, 1953.

7. Klingelhoeffer W. Terrarien-kunde. Vol. 1, 2, 3, u. 4. Alfred Kernen, Stuttgart, 1955.

8. Kourany M, Myers C.W, Schneider CR. Panamanian amphibians and reptiles and carriers of salmonella. American Journal of Tropical Medicine and Hygiene 19:632-638, 1970.

9. Le-Noc P, Brygoo ER. Les salmonelles des camaléons de Madagascar. Archives de l'Institut Pasteur 30:93104, 1962.

10. Lins ZC. Ocorrência do gênero salmonella em animais silvestres capturados na floresta amazônica. Anais de Microbiologia 12: 19-29, 1964.

11. Lins ZC. Studies on enteric bacteria in the lower Amazon region. II. Salmonella types isolated from wild reptiles in Pará State, Brazil. Revista de Microbiologia 2: 165-169. 1971 .

12. Marcus LC. Infectious diseases of reptiles. Journal of the American Veterinary Medicine Association 159:1626$1631,1971$.

13. Marcus LC. Diseases of snakes and turtles. New York Medicine Society Bulletin 8:3-12, 1971.
14. Moreno G, Lopes CAM, Belluomini HE, Pessoa GVA, Biasi P, Andrade JCR. Enterobactérias isoladas de anfíbios e répteis. Revista do Instituto de Medicina Tropical 15:122-126, 1973.

15. Murphy LB, Armstrong BL. Maintenance of rattlesnakes in captivity. Special Publication of the Museum of National History, 1978.

16. Murphy LB. A brief outline of suggested treatments for diseases of captive reptiles. Published by the Society of the Study of Amphibians and Reptiles and the Kansas Herpetological Society, 1981.

17. Page LA. Experimental ulcerative stomatitis in King snakes. Comell Veterinary 51:259-266, 1961.

18. Patrick R, Werkman CH. Notes on the bacterial flora of the Snakes. Proceedings of the Iowa Academy of Science $37: 330,1930$.

19. Reichenbach-Kline, Elkan ME. The principal diseases of lower vertebrates. Academic Press, New York, 1965.

20. Soerensen B, Amaral PA, Belluomini HE, Saliba MA, Correa HS, Hoge AR. Gota única visceral em serpentes. Crotalus durissus terrificus (Laurenti, 1768). Arquivos do Instituto Biológico 20:271-275, 1962.

21. Wagner CE. Mouth rot, a common disease of snakes. Bulletin of the Natural History Society 5:20-23, 1934.

22. Wallach JD. Medical sare of reptiles. Journal of the American Veterinary Medicine Association 155: $1017-$ $1041,1969$.

23. Williams FE, Freeman J, Kennedy E. The bacterial flora of the mouth of Australian venomous snakes in captivity. Medical Journal of Australian 11: 190, 1934.

24. Zwart D. Notes on salmonella infections in animals. Ghana Research Veterinary Science 2:150-169, 1961. 